Article

\title{
Slow Rise of Trade Politicisation in the UK and Brexit
}

\author{
María García \\ Politics, Languages and International Studies, University of Bath, Bath, BA2 7AY, UK, E-Mail: m.garcia@bath.ac.uk
}

Submitted: 18 December 2019 | Accepted: 16 March 2020 | Published: 31 March 2020

\begin{abstract}
Since the Brexit referendum, the UK government has deployed a vision of 'Global Britain' revolving around trade agreements, yet, this was not a key issue in the referendum. Drawing on politicisation literature, we explore the absence of visible activism around future trade policy, in contrast to moderate activity around the EU-US Transatlantic Trade and Investment Partnership (TTIP). We identify actors in UK TTIP mobilisation and trace their actions post-referendum, revealing politicisation as campaigners participate in channels for attempting to influence future UK trade policy. In the presence of these channels and lack of full clarity on future policy, to date, recourse to visible mobilisation in the public space has not yet occurred. Tracing this dynamic process, intertwining Brexit and trade policy, enables us to understand how politicisation of one process affects another. Crucially, given the context of re-nationalisation of trade policy, it allows us to explore how politicisation is operationalised in the absence of one of the key conditions for politicisation suggested in the literature: the transfer of authority to a more remote level of governance.
\end{abstract}

\section{Keywords}

Brexit; contestation; media; politicisation; trade; Transatlantic Trade and Investment Partnership

\section{Issue}

This article is part of the issue "Politicization of EU Trade Policy across Time and Space" edited by Dirk De Bièvre (University of Antwerp, Belgium), Oriol Costa (Universitat Autònoma de Barcelona, Spain/IBEI, Spain), Leif Johan Eliasson (East Stroudsburg University, USA) and Patricia Garcia-Duran (University of Barcelona, Spain).

(C) 2020 by the author; licensee Cogitatio (Lisbon, Portugal). This article is licensed under a Creative Commons Attribution 4.0 International License (CC BY).

\section{Introduction}

On 23 June 2016, the UK voted to leave the EU by a narrow margin. Emotional campaigning in the referendum gave way to heated exchanges in Parliament, Cabinet, and the media as to what shape Brexit should take. Since the referendum, the UK government has set out to create a 'Global Britain,' a beacon of free trade, centred around an independent trade policy. However, trade policy and trade agreements were not a principal feature of the referendum, and analyses of the votes attribute the result to preferences for certain politicians and migration positions (Clarke, Goodwin, \& Whiteley, 2017) and euroscepticism (British Social Attitudes, 2016), rather than trade policy preferences. UK governments have traditionally supported liberal trade policies, including within the EU. Cameron's government was an active proponent of TTIP (UK Government, 2015). May's and Johnson's governments have followed suit and pushed for a liberal independent trade policy. Perhaps more surprising is the absence of overt politicisation of trade in the public sphere and visible mobilisation, especially considering the significance given to control and sovereignty within the referendum campaign, and growing salience of trade policy in the public sphere. Initially, between July 2016 and March 2017, in a Nexis search only a few newspaper articles (in The Guardian and The Independent) highlighted the dangers of a UK-US trade deal, linking it to the concerns raised over TTIP by civil society (i.e., potential for National Health Service [NHS] privatisation, lower consumer standards). As time has progressed and May's, and especially Johnson's governments have taken a discursive turn towards the promotion of future trade deals, especially with the US, more media attention has been garnered to this. Expanding the Nexis search to end in December 2019, shows how news items on trade agreements have increased since the original deadline for Brexit of October 2018. Coverage is split between outlets critical of such a prospect (the same ones that denounced TTIP) and which also hold pro-EU editorial lines, 
and 'leave' supporting news outlets portraying a potential deal with the US as a benefit of Brexit (The Times, The Daily Telegraph).

Politicisation of trade policy in the last decade has been relatively weak in the UK in comparison with central European countries, but TTIP was politicised and inspired modest mobilisation. Social justice and environmental groups, and NHS workers and users demonstrated against it. Concerns over potential privatisation of the NHS was key in demonstrations. A number of organisations participated in cross-European initiatives such as \#StopTTIP and collected signatures for the Europe Citizens' Initiative against TTIP. They also coalesced around the UK-based platform, NoTTIP. TTIP was not a prominent feature in UK media, with the exception of The Guardian and The Independent newspapers. PostBrexit trade policy has likewise received relatively little attention. Considering that a number of the concerns raised around TTIP will arise in future trade negotiations, a similar degree of politicisation with regards at least to future negotiations with the US could be expected, especially as a network of information sharing and mobilisation was created in the UK in the TTIP contestation. However, thus far, strong politicisation and visible mobilisation around future UK trade policy has not materialised. This article, thus, asks the question of what has happened to the budding trade politicisation in the UK and why has it not expressed itself overtly yet concerning the longer-term trade policy of post-Brexit UK?

To answer the question the article charts the politicisation of trade policy across time: Within the TTIP controversy, during the referendum, and since the referendum, with respect to future UK trade policy. It does so by identifying the presence of the key components of politicisation as described in section two of this article. Issue salience of, and polarisation of views on, trade policy in the UK press is tracked using Nexis searches. Polarisation of views and mobilisation amongst societal organisations is traced through activist groups' positions and activities by mapping groups involved in anti-TTIP activism and their positions on the matter as derived from their websites.

The article proceeds as follows: The next section sets out the criteria that will be used to determine whether conditions for politicisation are present in the context of Brexit. Section 3 considers aspects of politicisation in the UK around trade policy in the context of TTIP and identifies key actors. Section 4 highlights the lack of salience of trade policy in the referendum. Section 5 traces the positions and actions of those actors after the referendum. The article concludes that politicisation is still there as associations involved in TTIP campaigning are actively participating in channels for (attempting) to influence the direction of the UK's future trade policy. In the presence of these channels, and lack of full clarity as to what the future trade policy will look like, recourse to demonstrations and more visible politicisation in the public space has not occurred.

\section{Conceptualising Politicisation}

Like most concepts in the social sciences, politicisation is imprecise. It has been defined as the 'expansion of the scope of conflict within a political system' (Grande \& Hutter, 2016), and as an 'increase in polarisation of opinions, interests or values and the extent to which they are publicly advanced towards the process of policy formulation' (de Wilde, 2007, p. 20). The existence of conflicting positions on an issue is, therefore, a key element of politicisation. Trade policies, especially since the move towards the inclusion of behind the borders issues in trade negotiation, have elicited conflicting positions on trade (see Young, 2017). Different interests, values, and positions are common in any society, and in and of themselves do not determine the politicisation of an issue. For politicisation to occur, an issue needs to be visible in the public domain (salience), the number of actors engaged in the issue has to increase, and there needs to be intensity of conflict over the issue (polarisation; Hutter \& Grande, 2014). Essentially, something is politicised if it appears often, if different opinions exist on the matter, and if different social actors are involved (Zürn, 2016, p. 166). Michael Zürn (2016) critiques a focus on media in studies of politicisation as an indicator of issue salience, and points to the importance of civil society mobilisation and activism, highlighting how awareness, social mobilisation, and public debate are also evidence of politicisation. He argues that politicisation occurs when an issue is salient (mentioned often in media), subject to polarised opinions, and when different groups find the issue of importance relative to other issues and worth mobilising for. For this reason, this article will take both salience of trade policy, with a focus on trade agreements, and societal activism on trade policy as indicators of politicisation.

Given the mobilisation, expansion in the number of actors, and polarisation that occurred in the UK towards TTIP, despite relatively low salience in general public debates, we would expect to see similar activities in the post-referendum scenario with respect to trade policy. Yet, so far this is not the case. From the above conceptualisation, we can hypothesise one reason: a relative lack of importance with respect to other issues, i.e., the more pressing task of how and what kind of Brexit to deliver. When it comes to Brexit, as a binary choice of leaving or remaining in the $\mathrm{EU}-\mathrm{a}$ 'soft' Brexit with a close economic relationship to the EU or a 'hard' Brexitpoliticisation is extremely high. The politicisation and polarisation of positions (amongst political groups, across parties, and the general population) have been evident in tight electoral results in the referendum and subsequent elections in 2017 and 2019. Even in the December 2019 election that delivered Prime Minister Johnson an absolute majority, 43 percent of voters favoured the Conservative Party and its diffuse Brexit message, whilst 52.6 percent backed parties opposed to Brexit (or a 'hard' Brexit; 'More people voted against Brexit,' 2019). 
The literature on politicisation has placed important emphasis on how the transfer of authority to new arenas of multinational governance leads to subsequent contestation of legitimacy of these new arenas, and considers this to be a key driver for politicisation (Costa, 2019; Peters \& Schaffer, 2013). Swen Hutter and Edgar Grande (2016) refer to three sources of conflict leading to politicisation: loss of sovereignty; threats to national identity; and transnational sovereignty. Whereas all three were present in the context of TTIP, and will be present in future trade agreements, we hypothesise that the absence of evident politicisation and civil mobilisation around trade policy at the present juncture lies in the fact that currently the discussion revolves around renationalising trade policy (i.e., regaining sovereignty). Moreover, the exact form renationalisation will take remains uncertain, and there is an opportunity structure in place through government and parliamentary consultations, enabling trade activists to participate in the process of designing the UK's future trade policy. Consequently, key drivers of politicisation are absent, for now.

\section{Budding Politicisation of Trade Policy in the UK}

The issue of EU membership has a long history of politicisation within the UK, particularly in the press (Daddow, 2012; Startin, 2015), but trade policy politicisation has been more limited to specific non-governmental organisations (NGO). NGOs activity around trade started with the contestation of the expansion of trade liberalisation to services within the negotiation of the General Agreement on Trade in Services in the late 1980s-1990s, which entailed transferring some authority over policy decisions on services to an international organisation, whose legitimacy was questioned by opponents. At that time, NGOs founded the Trade Justice Movement network, which has since acted as a lobby group, and has been heavily involved in transnational NGOs networks such as Seattle to Brussels exerting pressure on the European Commission (Strange, 2013). As throughout this time international trade negotiation authority has laid with the European Commission, these groups focused their efforts at the European level. Nonetheless, they also lobbied UK parliamentarians to support their positions on trade and influence the UK government's views, and through it, the EU's trade policy (Strange, 2013).

In the context of TTIP negotiations, EU trade policy garnered more attention within public debates across Europe, including in the UK, signalling a budding politicisation beyond networked NGOs already active in trade policy. An analysis of key newspapers in the UK reveals that whilst there was some reporting on the matter, its salience across the broad spectrum of papers was very limited. A search for articles on TTIP between 2013 (launch of TTIP negotiations) and December 2016 (suspension of negotiations) on the online news archive, Nexis, reveals only two major newspapers took an interest in reporting on TTIP (The Independent and
The Guardian). Both expressed concerns with secrecy in the negotiations, the potential impact of controversial investor-state dispute settlement (ISDS) provisions, and both took positions against the agreement. Other outlets barely covered the developments. The concentration of coverage was limited to the more left-leaning press, showing that issue salience, one of the key conditions for politicisation highlighted in the literature, was limited.

As Michael Zürn (2004) points out, politicisation needs to also be observed beyond media debates in other parts of the public domain. In terms of civil society mobilisation, TTIP galvanised certain groups in the UK in a more visible way, despite overall support for the deal according to Eurobarometer surveys, where only 19 percent of UK respondents opposed TTIP in both 2014 and 2016 (European Commission, 2016; European Parliamentary Research Service Blog, 2015). Organisations opposed to TTIP, concerned over potential transfer of authority to a transatlantic regulatory body, came together under the NoTTIP Platform, which organised and publicised marches and demonstrations and encouraged the public to sign the European Citizens' Initiative against TTIP. Importantly, activists with experience in trade policy in the UK and EU, like Trade Justice Movement, mobilised further groups. This helped to increase the salience of the issue, and the number of actors involved, fulfilling some of Swen Hutter and Edgar Grande's (2014) criteria for politicisation.

Of the 54 organisations listed in NoTTIP's website, six represented large trade unions, one was the national branch of a transnational NGO (Friends of the Earth), one a political party (Greens), and two established NGOs working on social justice and trade matters (Global Justice Now, War on Want). The majority were small-scale grassroots campaigning groups, interested in single issues affecting their local communities (e.g., fracking, water use, austerity). Within the grassroots organisations, listed in Box 1, three distinct groups can be identified: environmental, anti-austerity, and pro-public services-although the final two are closely related as anti-austerity groups' campaign for greater spending and public service provision.

Anti-TTIP activism by smaller groups was promoted by the larger groups, who raised awareness of potential dangers in TTIP and encouraged participation in campaigns. The websites of smaller groups feature position papers and materials on TTIP produced by War on Want and Global Justice Now or direct links to these. These relationships reflect wider European patterns of activism against TTIP. The role played by well-resourced German NGOs, with prior experience opposing genetically modified organisms in food, as instigators of antiTTIP activism has been well-documented (Bauer, 2015, 2016; De Bièvre, 2018). Activists with experience in antiglobalisation protests from the pan-European Seattle to Brussels network also took up the TTIP cause and mobilised in opposition (De Ville \& Siles-Brügge, 2015). Anti-TTIP campaigns were, thus, organised in a top-down 
Box 1. Organisations in NoTTIP.

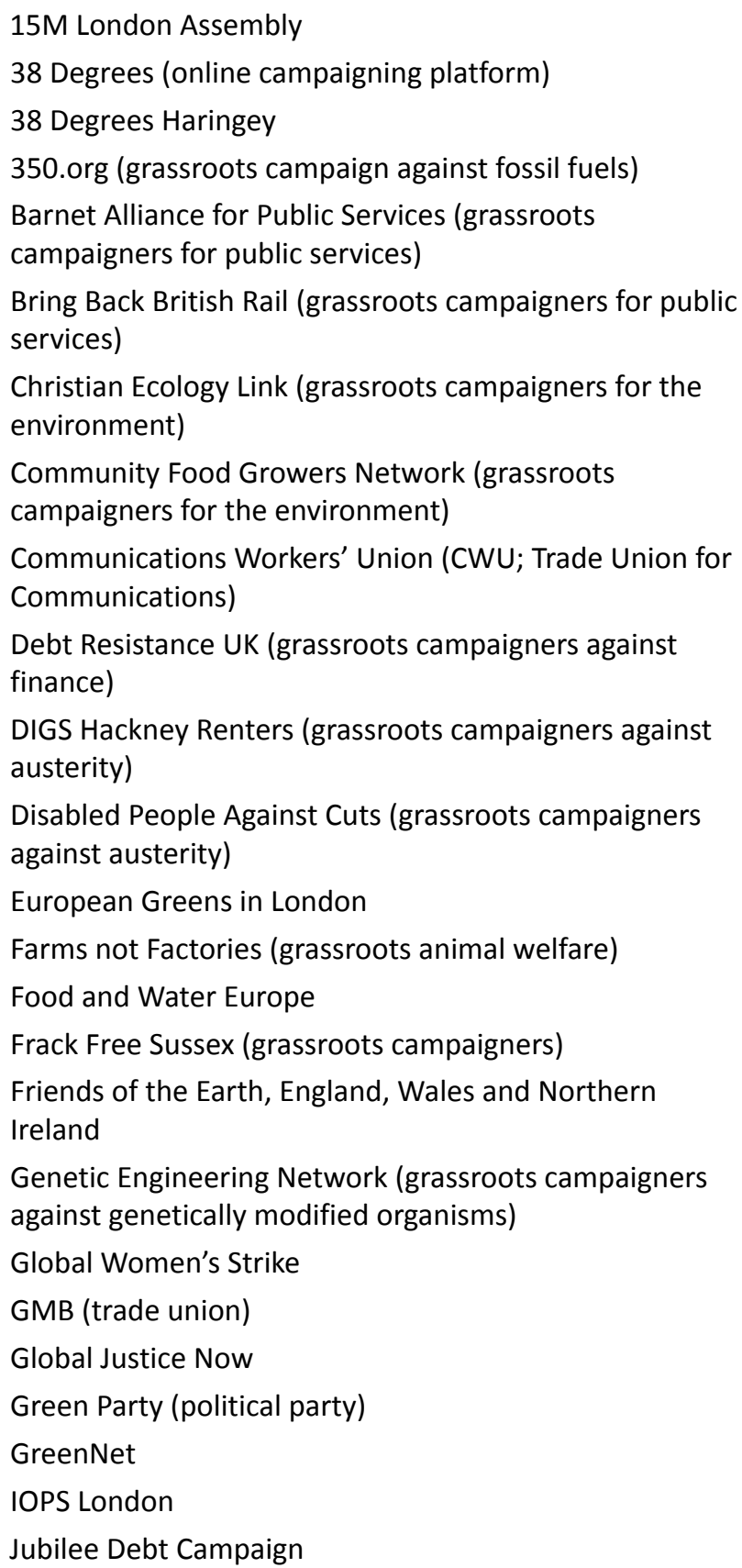

manner by large experienced civil society organisations (Eliasson \& García-Duran-Huet, 2018), taking advantage of social media and exaggerated positions to attract public and media attention (De Bièvre, 2018).

The larger UK groups (trade unions, Green Party, large NGOs) involved in TTIP also feature in the list of members of the pan-European StopTTIP Platform, which coordinated the European Citizens' Initiative. StopTTIP served as an information point collating the activities of various groups and events organised by members throughout Europe. Additionally, it promoted the naming and shaming of members of the European Parliament voting in favour of proceeding with TTIP negotiations. UK participants in StopTTIP, listed in Table 1, had a history
Keep Our NHS Public (grassroots campaigners for public services)

Left Unity

Lewisham People Before Profit

London Federation of Green Parties

Low Impact Living Initiative

New Internationalist magazine

Occupy London (grassroots campaigners against capitalism, finance)

OurNHS (campaign for public services part of OpenDemocracy)

People's Assembly Against Austerity (grassroots against austerity)

Power for the People (grassroots for public services)

Public and Commercial Services Union (trade union)

Reclaim the Power (grassroots campaigners for public services)

Red Pepper (online magazine)

Rising Tide UK

Roj Women's Association (RWA)

STOPAIDS

Student Stop Aids Campaign

SumOfUs

The Landworkers' Alliance

UK Uncut (grassroots campaigners against austerity) UNISON (trade union)

Unite (trade union)

University and College Union (UCU)

War on Want

We Own It

Women's International League for Peace and Freedom Young Friends of the Earth (International NGO) Young Greens (political party)

of engagement with peers across the EU (e.g., through the European Trade Union Confederation, Seattle to Brussels) and belonged to information and resource sharing networks through which they gained heightened awareness of TTIP. As mentioned previously, they were also largely responsible for raising awareness and encouraging smaller groups in the UK to take up the TTIP cause.

Amongst groups that mobilised in the UK, protection of public services was a key issue, as per their website statements. For trade unions and grassroots organisations, public services were linked to the controversial matter of ISDS. Environmental and regulatory concerns were the key motivation for environmental groups. War on Want, and Global Justice Now, were especially ac- 
Table 1. UK organisations in StopTTIP.

\begin{tabular}{|c|c|c|}
\hline Organisation & Type of Organisation & Main TTIP issue \\
\hline GMB Union & Trade Union & Privatisation, regulation \\
\hline NASUWT The Teachers' Union & Trade Union & \\
\hline National Union of Teachers & Trade Union & Privatisation \\
\hline Public and Commercial Services Union & Trade Union & Threat to public services \\
\hline Scottish Secondary Teachers' Association & Trade Union & \\
\hline The Educational Institute of Scotland & Trade Union & NHS protection \\
\hline UNISON & Trade Union & Protect public services \\
\hline Unite the Union & Trade Union & Public services \\
\hline University and College Union & Trade Union & \\
\hline 38 Degrees & Petition Platform & ISDS Corporate power \\
\hline Artists against TTIP & Awareness raising & \\
\hline Bring Back British Rail & Advocacy group renationalise rail & \\
\hline $\begin{array}{l}\text { CAWN Central America Women's } \\
\text { Network }\end{array}$ & $\begin{array}{l}\text { Advocacy, research on women's } \\
\text { rights }\end{array}$ & \\
\hline EcoNexus & Activism, research network & $\begin{array}{l}\text { Environment/Genetically- } \\
\text { modified organisms }\end{array}$ \\
\hline $\begin{array}{l}\text { Friends of the Earth, England, } \\
\text { Wales \& Northern Ireland }\end{array}$ & Environmental group & \\
\hline Friends of the Earth, Scotland & Environmental group & \\
\hline Global Justice Now & Advocacy, campaigning & Anti-trade \\
\hline Green Party, England \& Wales & Political party & Environment/Transparency \\
\hline Gun Control Network & Single issue activism & \\
\hline Highland \& Islands against Fracking & Environmental activism & \\
\hline Jubilee Debt Campaign & Poverty alleviation activism & Transparency/Regulatory race to bottom \\
\hline National Justice \& Peace Network & Religious advocacy & \\
\hline People and Planet & $\begin{array}{l}\text { Environmental and social justice } \\
\text { activism }\end{array}$ & \\
\hline Power for the People & Advocacy & Renationalise UK energy network \\
\hline \multicolumn{3}{|l|}{$\begin{array}{l}\text { Scottish Education and Action } \\
\text { for Development (SEAD) }\end{array}$} \\
\hline Soil Association & Organic certification body & \\
\hline Trade Justice Movement & Coalition of civil society groups & $\begin{array}{l}\text { Regulation/ISDS/Effect on developing } \\
\text { world }\end{array}$ \\
\hline StopTTIP UK & Platform grouping opponents & Transparency/Corporate power/ISDS \\
\hline \multicolumn{3}{|l|}{ Student Stop AIDS Campaign } \\
\hline The GAIA Foundation & $\begin{array}{l}\text { Activism, biocultural diversity, } \\
\text { ecology, community projects }\end{array}$ & Corporate power/Seeds/Monsanto \\
\hline UK National Hazards Campaign & Campaigning, resource centre & \\
\hline
\end{tabular}

tive and held a much broader opposition to TTIP and to (neo)liberal trade policies. The Trade Justice Movement, to which many of the NGOs mentioned and unions also belong, aggregated resources from members and produced research on trade matters (including TTIP, development, and now Brexit and trade policy). It actively made submissions to Parliament, Government, and the European Commission, advocating for more progressive trade policies. Although a key salient issue in the UK context was the perceived threat to public services, especially the NHS, the broader concerns around ISDS regulation and secrecy that galvanised pan-European mobilisation were also present (see Bauer, 2016; De Ville \& Siles-Brügge, 2015).

NoTTIP and StopTTIP websites stopped being updated with the suspension of TTIP negotiations in 
late 2016. However, StopTTIP has been rebranded as StopISDS and campaigns for a wholesale dismantlement of ISDS arrangements and a binding UN Treaty to hold corporations liable for human rights violations (StopISDS, n.d.). Except for a few cases detailed in the Section 5, most of these groups have no sections on their websites on post-Brexit trade policy. Seemingly, they have retreated back to single-issue concerns, and, for now, are not highlighting and mobilising around the interconnection between their issues and potential future trade policies.

\section{Trade in the Referendum Campaign}

Although trade policy lies at the heart of the UK's future relationship with the EU, and post-Brexit UK, the intricacies of this issue were not elaborated upon in the lead up to the referendum. Polarisation of positions on EU membership, which had existed for decades, came to a crescendo in the campaigns. Analyses reveal that the conduct of the referendum (including accusations of lies on both camps), business and the domestic economy, and immigration were the issues that dominated media coverage and debates (Deacon, Harmer, Downey, Stanyer, \& Wring, 2016). The Remain camp sought to make the economy the core issue of the referendum, and discussed advantages of membership and perils of leaving the EU, whilst the Leave camp focused on critiquing Remain supporters for 'project fear' (Moore \& Ramsay, 2017, p. 40). Rehearsing these tropes in the media and campaigns meant that more complex issues, such as the interaction of Brexit with trade policy, were insufficiently probed.

Trade did feature in the referendum campaign but was obscured by other matters. It was an aspect of broader economic arguments for remaining in the EU for the Remain camp (Britain Stronger in Europe, n.d.). Within the Leave narrative of 'taking back control' (mainly of borders, laws, and budgets), trade policy featured as another area to renationalise. The Vote Leave campaign included trade as number four of its five key points, after NHS, immigration, and border control. Trade was encapsulated as: "We'll be free to trade with the whole world" (Vote Leave, 2016). Despite the focus on 'taking back control' the Leave campaign failed to notice that future trade agreements could have a constraining effect on UK domestic policies. Their discursive 'strategies were aimed at delegitimising the EU as dominating and constraining the UK in its trading potential and meddling with its national sovereignty' (Zappettini, 2019a, p. 416). However, for the majority of voters the decision to vote leave was not determined by liberal economic imaginaries of Brexiteers, but rather material considerations influenced by narratives around control and migration (Clarke et al., 2017), and a desire to express their dissatisfaction with political elites and with their material conditions (Green et al., 2016; Koch, 2017). Future UK trade policy was, thus, an issue of low salience during the referendum. Extreme polarisation occurred around the immediate and pressing Remain-Leave dichotomy, but not trade policy.

A search of UK national newspapers in Nexis in the lead-up to the referendum, between the start of April and 23 June 2016, reiterates the low salience of future trade policy. Only eleven articles featured the words 'trade agreements' in the title. One was in The Independent highlighting the threat of Brexit for existing trade agreements to which the UK is party through the EU. Nine were in The Guardian, covering the same issue, or referring to Swiss arrangements with the EU. One was in The Telegraph, penned by leading Brexit economist Patrick Minford, arguing for the need to drop EU protectionist trade policies. A further 183 articles mentioned trade agreements elsewhere, of which 99 referred to Trump's position on the North American Free Trade Agreement (NAFTA). The remaining 84 explained how following Norway's or Switzerland's relationship with the EU, or having a preferential trade agreement with the EU, would differ from EU membership. In brief, the media focus on trade was not so much on future trade policy, but on explaining the trading options with the EU should the UK vote in favour of leaving the EU.

In terms of societal mobilisation, during the referendum, most of the organisations involved in TTIP were unengaged in trade-related mobilisation. An analysis of their positions, based on their referendum statements on websites, reveals most did not have a position on the referendum, partly because their members themselves held different positions on Remain and Leave. Exceptions include the Green Party, Unite, and Friends of the Earth, who supported the Remain option, based on fear of erosion of environmental and social regulatory protection outside the EU. The trade union GMB (in Scotland) also supported Remain. Of the major NGOs active in the UK anti-TTIP camp, Global Justice Now, after consultation with its members, supported Remain. War on Want advocated for leaving the EU to enact a progressive and left-inspired Brexit including a reversal of preferential trade agreements.

Post-referendum, May's government rallied around a diffuse concept of a 'Global Britain' seizing business opportunities beyond Europe (Zappettini, 2019b). This became a mantra for the new Department for International Trade and incipient trade policy. Yet, it is an area largely undebated during the referendum, and that has been entangled in post-referendum discourses on the negotiations with the EU, the outcome of which will determine any future UK trade policy.

\section{Post-Referendum Positions on Trade Policy}

There has been a resurgence post-referendum in the salience of trade policy in the public sphere, not least given the trade related aspects of the withdrawal from the EU. A search of UK newspapers between July 2016 and December 2018 on Nexis, reveals 17,420 articles with the words 'trade agreements' in the headlines. 
Articles often deal with the connection with the future relationship with the $\mathrm{EU}$, and with plans to negotiate new agreements. Whilst The Independent continues to lead the coverage with 2,924 articles, newpapers that had barely focused on TTIP have also covered trade agreements post-referendum (e.g., Telegraph, Mail, Express). The latter tend to focus on elements relating to exiting the EU (e.g., a trade agreement being contingent on a divorce bill, the appointment of new trade negotiators). The Independent and The Guardian continue their line of raising concerns over potential trade deals that contain ISDS, regulatory backsliding (as during TTIP coverage), and highlighting the dangers of a 'hard Brexit.' These are the only general outlets that highlight the potential for national sovereignty erosion that can result from trade agreements. The salience of trade in the media and public debates has become evident, however, it remains largely intertwined with the positions and polarisation on the EU, rather than treated as an independent issue.

In terms of civil society groups' activism postreferendum, groups active on TTIP have yet to engage in obvious public mobilisation on trade, e.g., public demonstrations. However, an analysis of websites uncovers clear positioning on trade policy by some groups and participation in policy-shaping consultations. A few of these organisations have specific Brexit positions on trade, revealing largely pro-EU stances. The National Union of Teachers features a statement that any post-Brexit trade policy must include a commitment against privatisation. War on Want focuses on the need to "ensure that the Leave vote cannot be claimed as a mandate for the UK to develop its own trade deals on the negative lines that it has traditionally supported within the EU" (War on Want, 2016), and calls for a progressive trade policy, in a briefing that is also available on the National Justice and Peace Network website. UNISON highlights the potential for trade deals to undermine devolution citing, and including a link to, a Global Justice Now report. Other trade unions under the Trade Unions Congress (TUC) are active in attempting to influence Brexit. They are concerned about the future of the country being hijacked by the right, and propose an alternative vision featuring support for migrants and refugees, no privatisations, an end to austerity, and maintaining worker rights and protections. The Soil Association (organic certification body) includes a statement on the importance of 'how we trade' for food and farming, and advocates for the UK retaining alignment to the EU rather than the US, and for ensuring high food standards in future trade agreements.

Unsurprisingly, the two most active organisations against TTIP are articulating broader positions on the future of trade policy. War on Want highlights its key principles for trade policy, which encapsulate its objections to TTIP: protecting workers's rights, the NHS, and public services; development-friendly trade policies; and democratic inputs into trade policy. Global Justice Now has been especially active in trying to shape post-Brexit trade policy. They have mobilised over 60,000 people to send submissions to the Government's public consultation on the future of trade policy. When former Secretary for International Trade, Dr. Fox, published the new Trade Bill, they launched the campaign to inform and lobby Members of Parliament (MPs). They have produced work regarding the effects of trade on devolution, and are working with Scottish activists to influence MSPs. Their aim is for future trade policy to be more transparent, democratic, and equitable than the EU's. Their vision for trade agreements that exclude ISDS, include high standards, respect labour and environmental standards, and carve-out public services, counters many of the concerns TTIP prompted. In this regard, we can observe that larger networks with past experience lobbying on trade policy in the UK and the EU, who instigated anti-TTIP mobilisation, continue their influencing work within the context of the UK's future trade policy.

Encouraging their members to support their submissions to Government consultations follows the same pattern established in the anti-TTIP movement. During TTIP negotiations, the European Commission launched a public consultation on ISDS. It reported that 97 percent of the submissions had been coordinated through online platforms with the exact same text being submitted (European Commission, 2015, p. 3). This was coordinated by pan-European StopTTIP platform. Large UK NGOs that stoked anti-TTIP sentiment are, thus, mobilising the UK part of their networks to take advantage of opportunities to make their positions known to policymakers, and using some of the same tactics as during anti-TTIP mobilisation. A key difference, however, lies in the absence of civil demonstrations and protests. During the campaign against TTIP, 87 public actions were organised in the UK, representing 10 percent of actions accross the EU (Caiani \& Graziano, 2018, p. 1038). TTIP protests in the UK followed on from activities in Germany, Austria, and France, initially orchestrated by the activist group Attac (De Bièvre, 2018), and were fewer and less wellattended than in other EU member states. This was partly due to more political and discursive opportunities open to the anti-TTIP movement in the UK through the positions of independentist and opposition parties (Caiani \& Graziano, 2018), as well as the Trade Justice Movement's years of lobbying MPs (Strange, 2013), and the general lack of awareness on TTIP given very low media salience. In the post-referendum context, where the full direction and content of future UK trade policy and trade negotiations remains imprecise, and with the existence of opportunities to participate in policy consultations, large UK civil society groups working on trade policy are eschewing the high visibility activities that their European partners institigated against TTIP. Instead they are continuing the engagement and lobbying activity that they have undertaken for years to try to shape the direction of future policy.

The process of renationalisation of trade policy, and the need to develop a new policy, is creating a unique opportunity for civil society groups with expertise in trade 
to participate in policy creation and attempt to shape future UK policy. It is also bringing trade policy-making to a level of governance that is more approachable for them, and where they can leverage their past experiences lobbying MPs and ties developed with MPs and independendist parties during the TTIP campaigns. Being able to access policy-making circles, and the consultative processes in policy-making, eliminates the immediate need to engage in in the kinds of public protest activities that charaterised politicisation of trade policy in the context of TTIP. This possibility for influencing runs counter to the authority transfer hypothesis that explains the motivation behind politication in the literature, when groups react to the shift of decision-making powers to a more international level of governance that they see as less legitimate, and to the consequent dilution of national sovereignty this entails (Costa, 2019; Peters \& Schaffer, 2013).

The present juncture of trade policy creation, has enabled activist groups to take a leading role in suggesting how future UK trade policy should be organised. The publication of A Trade Governance Model that Works for Everyone (hereafter Model) in response to Government consultations represents an interesting development. The Model was co-authored by business associations, trade unions, and a trade NGO (Confederation of British Industry, ICC United Kingdom, Trade Justice Movement, and UNITE the Union). It advocates for a trade policy that ensures consensus-building (through stakeholder participation at all stages), transparency (with access to documents at all stages), scrutiny (in Parliament, with votes), and a holistic approach to trade (including credible mitigation plans, and labour and environmental objectives) (Trade Justice Movement, 2018). Unlike during TTIP negotiations, when business groups were largely in support of TTIP (Dür \& Lechner, 2015), the Model brings the major UK business associations together with trade unions and NGOs to produce a document with language that incorporates concerns raised by anti-TTIP groups. The most active and knowledgeable groups from the antiTTIP campaigns are making use of all the channels available to them through government consultations and engaging with groups previously on the opposite side to demand improved trade policies, without the need to engage in high visibility public demonstrations. The strategy is about taking advantages of a unique opportunity structure presented by the repatriation of trade authority from Brussels to London. This situation of renationalisation contrasts with the case of TTIP. In the latter, the possible creation of a transatlantic body for regulation and transfer of regulatory decision-making powers to this remote body was a key aspect giving rise to politicisation and opposition (Costa, 2019). Such a transfer of authority through executive multilateralism is an important condition for politicisation (Peters \& Schaffer, 2013; Zürn, 2004). In the early evolution of a UK trade policy, this condition is absent. Instead, it is the type of future trade policy, a more progressive socially and envi- ronmentally sensitive trade policy, as advocated by the Trade Governance Model signatories, or a more neoliberal trade policy, that instigates divergent opinions and potential politicisation.

The Government's White Paper on Preparing for our Future Trade Policy (UK Government, 2017) is generic in its content, and includes many demands of civil society. It claims trade policy will be inclusive and transparent. A consultation with stakeholders on how to achieve this has been launched. It purports trade policy will support developing countries. It commits the Government to maintaining high standards of consumer, worker, and environmental standards in trade agreements, and ensure trade policy works for everyone through the use of trade remedies and the Industrial Policy. The absence of detail as to how to achieve this makes it impossible to ascertain whether trade policy will shift towards the type of trade policy that has been advocated by activist groups. The language and commitments in this document, and numerous consultations taking place, could indicate an awareness of the need to incorporate challenging voices into trade policy, to prevent the type of opposition that TTIP instigated. One concrete action that the Government has taken in the direction of incorporation of non-government actors and views in trade policy, and, perhaps, to compensate for the relative absence of in-house expertise on trade, has been the creation of a Strategic Advisory Group of 16 representatives from business and civil society within the Department for International Trade (DIT). This is reminiscent of one of the European Commission's reponses to anti-TTIP mobilisation, namely the creation in 2017 of an Expert Group on Trade Agreements composed of civil society and business representations. Box 2 shows the initial members of the UK's Strategic Advisory Group.

Institutionally, the UK has had to create trade policy capacity since the referendum, starting with the creation of DIT. The problem of lack of in-house expertise has been a common criticism raised against DIT and the Government (de Jonquieres, 2019; Illot, Skelt, \& Rutter, 2017; 'Meet the man,' 2019). High profile appointments of former EU negotiators and those of other nationalities, and the launch of a new dedicated trade career stream within the civil service in 2019 , form part of the Government's preparations for an independent trade policy. The time lag involved in this institutionbuilding process and political delays given the paralysis in Parliament on Brexit prior to the 2019 election has meant that the UK still has not fully articulated its future trade policy. This makes it difficult for civil society organisations to respond and determine whether public mobilisation strategies such as those orchestrated against TTIP are pertinent. For now, organisations are exploiting opportunities to inform policy-makers and politicians (particularly pro-EU ones) and to respond to Parliamentary enquiries and DIT white papers to ensure their positions and visions for future trade policy are noted, as trade policy authority is repatriated to the national level. 
Box 2. DIT's strategic trade advisory group (2019-2020).

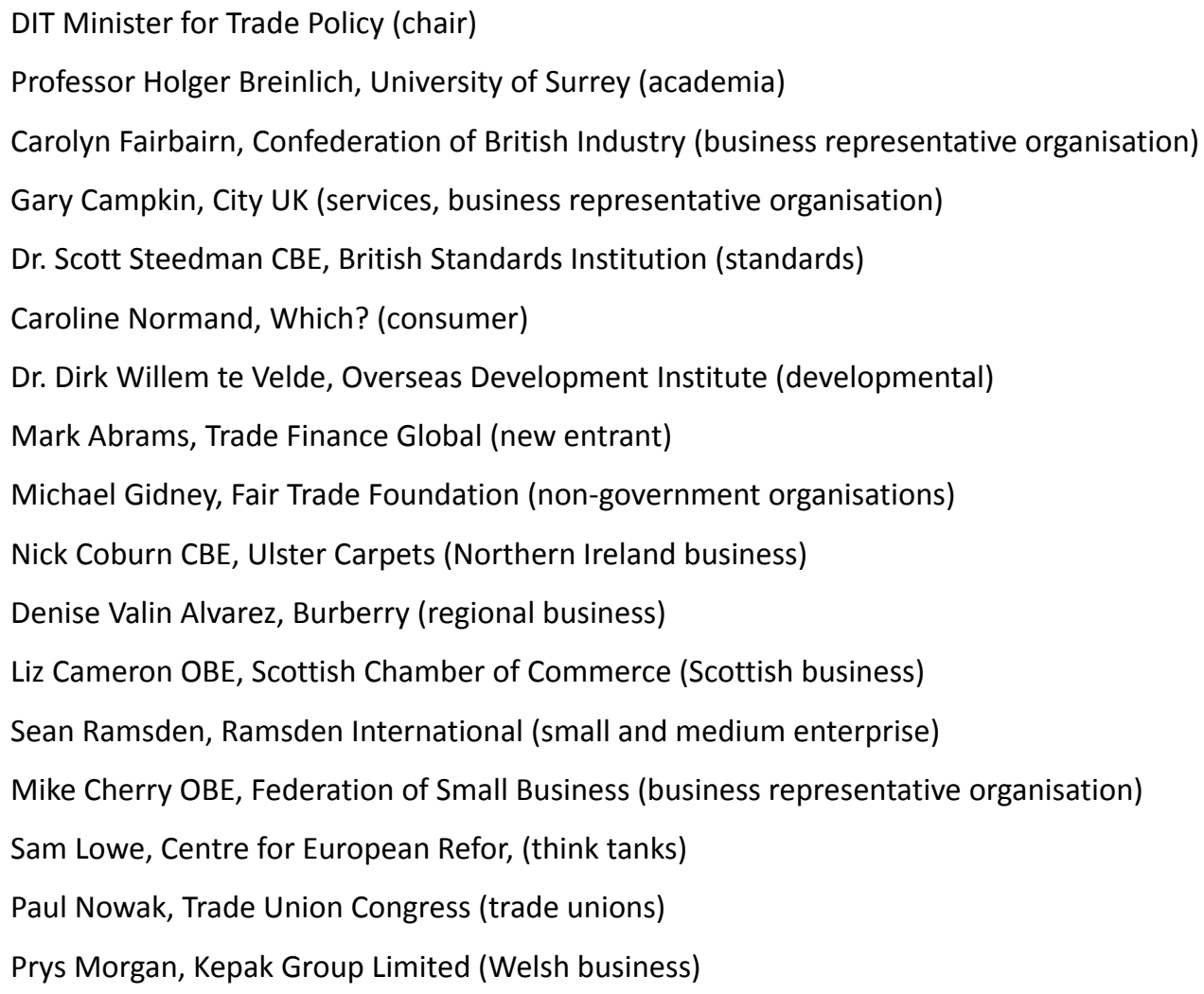

\section{Conclusion}

This article has tracked politicisation of trade policy in the UK since TTIP negotiations, by looking at newspaper stances on the matter, and at the positions and actions of civil society groups and campaigners. The article has found that, whilst the salience of trade policy and trade agreements has increased exponentially, politicisation of future UK trade policy, for now, remains contained. As the analysis of newspaper articles on trade conducted on Nexis has shown, there has been a marked increase in the salience of trade issues in the UK. Trade and trade agreements have become very salient in the media and political debates, and views on these matters are highly polarised, fulfilling some of the key conditions for politicisation identified in the literature (Hutter \& Grande, 2014), but this has not translated into visible mobilisation as in the case of TTIP. As Michael Zürn (2016) highlights, a critical factor determining politicisation is for a salient issue, subject to polarised opinions to be deemed relatively more important than other issues. To date, post-Brexit trade policy has been subsumed into the more pressing matter of delivering Brexit, in the hierarchy of issues. The marginal referendum result, and May's loss of a Parliamentary majority in 2017, created a space for politicians across the political spectrum, and for society, to re-enact the tropes of the referendum in attempts to either stop Brexit, or ensure a 'soft' Brexit. Future UK trade policy has, however, played a role at Parliamentary level in the battle to determine the meaning of Brexit in policy terms. The European Research Group of the Conservative Party, with its vision for an 'unshackled' UK and neoliberal policy inclinations, helped steer May's Brexit negotiations with the EU towards a looser future relation governed by a trade agreement, facilitating an independent trade policy. Without a clear majority for May's projected Brexit, groups concerned about this and possible implications of other future trade agreements, focused their energies in different ways. Parliamentarians continued to stymie the passing of the Withdrawal Agreement and to seek amendments to steer Brexit in other directions, rehearsing the Leave-Remain, and 'soft' vs. 'hard' Brexit dichotomies. The 2019 electoral campaign was also run along these lines. The Conservatives focused on a vague 'Get Brexit Done' slogan that obscured the underlying choices and challenges involved in Brexit. The Liberal Democrats campaigned on a Remain platform supportive of a second referendum, and Labour supported a renegotiation of the Withdrawal Agreement and a confirmatory public vote. Again, politicisation occurred along the pro- and anti-EU axis instead of longer-term economic and trade policy consequences.

The scrutiny of the positions of civil society organisations that had been active against TTIP, as derived from their websites and policy documents, has revealed that the key groups (Global Justice Now, War on Want, Trade Justice Movement), have articulated clear positions on 
post-Brexit trade policy and have been attempting to influence its evolution. They have produced information and research to steer policy-makers towards a Brexit with close relations to the EU. As regards to trade policy, they have engaged in opportunities for influence garnered by the creation of a new institutional set-up for trade policy. Interesting evolutions in the behaviour of these groups have also been observed, such as siding with business interests to produce a progressive Model Trade Governance plan submitted to the DIT. Civil society groups with interests in trade have also been participating in Government consultations on the future of trade policy, which are creating an opportunity to pre-empt rather than react to policy choices and consequences, within the process of regaining sovereignty over trade policy. Future research will have to analyse if these opportunities actually translate into genuine influence in shaping future trade policy. Nonetheless, the initial inclusion of civil society groups and, at least, the theoretical commitment to greater inclusivity as per the paper Preparing for Our Future Trade Policy, and the creation of the Strategic Advisory Group of representatives, can help to enhance the legitimacy of trade policy and counter potential politicisation and subsequent mobilisation. Opinion polls suggest that there is support for the Government's agenda for a liberal trade policy, with 66 percent of those polled in favour (Vasilopoulou, Keith, \& Taalving, 2020), something that further limits the immediate potential for public mobilisation. Positive attitudes towards trade become more complex when respondents are asked about their impressions of post-Brexit trade agreements, with 42 percent holding positive views and 41 percent negative perceptions, tinged with some of the concerns voiced in the left leaning media around US chlorinated chickens, and showing a clear correlation with personal positions on Brexit (Vasilopoulou et al., 2020). Trust in Government in the UK remains low at 40 percent, despite increasing by four percent since the 2019 election, according to the Edelman (2020) Trust Barometer. In a climate of distrust and continued high polarisation along Brexit and anti-Brexit lines, the potential for politicisation and more overt public contestation of post-Brexit trade agreement negotiations remains significant.

With trade policy subsumed, for now, in the Brexit process, and opportunities for civil society organisations to participate in the shaping of future trade policy as new institutions are created to deal with the renationalisation of trade policy, politicisation of UK trade policy remains partial. Despite growing salience, the relationship with the EU continues to top the hierarchy of issues. Whilst there are polarised views on the future trade policy, activist groups have managed to forge a network, including business representatives to collaborate in the proposal of a more progressive trade policy (Model Trade Governance). They also have opportunities to attempt to determine future policy, further containing the need to engage in the mobilisation of the public and smaller civil society groups that were mobilised against TTIP.
However, full clarity on how the Government and DIT will incorporate civil society in future trade policy and negotiations, on how an inclusive, fair, and balanced trade policy will be achieved, is still forthcoming. Should trade policy take a different turn, for example, as key players in the anti-TTIP mobilisation could shift tactics, and once again engage their networks to contest unwanted developments. The 2019 election result handing Johnson a government majority, facilitated parliamentary approval of his renegotiated Withdrawal Agreement, opening the way for Brexit and eventual trade agreements. In the first days post-election, Johnson's government's tone hardened with respect to the future relation with the EU. He rejected an extension of the post-Brexit negotiation period. Former cabinet members stated the Government wished to diverge from EU regulations (which would enable the hard Brexiteers' neoliberal vision and controversial trade agreements with the US; 'David Davis: UK will diverge,' 2019). Moves were also made to facilitate changing EU laws post-Brexit through lower courts ('Lower courts can roll back,' 2019). Whilst it remains unclear how future trade agreements and policies will evolve, and how the commitment to inclusion and scrutiny will be implemented in the new political situation of a majority Brexit parliament, if the initial stance of post-election days is a harbinger of a turn towards a more aggressive neoliberal trade policy outside the EU, active contestation and mobilisation against this is more likely to errupt. Within the context of Brexit, salience of trade and trade agreements in the media and Parliamentary debates has increased dramatically since the days of TTIP. As Brexit becomes a reality, the debate will turn more explicitly to trade agreements and future trade policy, and it will rise in the hierarchy of issues, making more visible mobilisation and politicisation more likely, as future trade negotiations, especially with the US, will involve a potential loss of sovereignty, which was a key factor influencing politicisation of TTIP (Peters \& Schaffer, 2013). Other key underlying conditions for politicisation (salience and polarised opinions) already exist. It is the more pressing matter of Brexit-the lack of full clarity around future trade policy-and with it the hope that demands for a progressive trade policy may yet materialise, that has kept politicisation at bay and activist groups from engaging in more visible mobilisation.

\section{Acknowledgments}

Thanks to participants at the EU-NormCon Trade Politicisation Workshop in Barcelona 2 July 2018, editors and referees for their comments. Mistakes and omissions remain the sole responsibility of the author.

\section{Conflict of Interests}

The author declares no conflict of interests. 


\section{Supplementary Material}

Supplementary material for this article is available online in the format provided by the authors (unedited).

\section{References}

Bauer, M. (2015). Campaign-triggered mass collaboration in the EU's online consultations: The ISDS-in-TTIP case. European View, 14(1), 121-129.

Bauer, M. (2016). Manufacturing discontent: The rise to power of anti-TTIP groups (ECIPE Paper 2/2016). Brussels: ECIPE.

Britain Stronger in Europe. (n.d.). Get the facts. Britain Stronger in Europe. Retrieved from https://www. strongerin.co.uk/get the facts

British Social Attitudes. (2016). Brexit: Litmus test or lightning rod? British Social Attitudes. Retrieved from https://www.bsa.natcen.ac.uk/latest-report/ british-social-attitudes-34/brexit.aspx

Caiani, M., \& Graziano, P. (2018). Europeanisation and social movements: The case of the Stop TTIP campaign. European Journal of Political Research, 57(4), 1031-1055.

Clarke, H. D., Goodwin, M., \& Whiteley, P. (2017). Why Britain voted for Brexit: An individual-level analysis of the 2016 referendum vote. Parliamentary Affairs, 70(3), 439-464.

Costa, O. (2019). The politicisation of EU external relations. Journal of European Public Policy, 26(5), 790-802.

Daddow, O. (2012). The UK media and 'Europe': From permissive consensus to destructive dissent. International Affairs, 88(6), 1219-1236.

David Davis: UK will diverge from EU trade rules. (2019, December 16). Politico. Retrieved from https://www. politico.eu/article/david-davis-uk-will-diverge-fromeu-trade-rules

Deacon, D., Harmer, E., Downey, J., Stanyer, J., \& Wring, D. (2016). UK news coverage of the 2016 EU Referendum: Report 5 (6 May-22 June 2016). Loughborough: Loughborough University.

De Bièvre, D. (2018). The paradox of weakness in European trade policy: Contestation and resilience in CETA and TTIP negotiations. International Spectator, 53(3), 70-85.

de Jonquieres, G. (2019, December 12). Tory politicians have much to learn about trade policy. Prospect Magazine. Retrieved from https://www.prospect magazine.co.uk/economics-and-finance/torypoliticians-have-much-to-learn-about-trade-policynegotiations-brexit

De Ville, F., \& Siles-Brügge, G. (2015). TTIP: The truth about the transatlantic trade and investment partnership. Hoboken, NJ: John Wiley \& Sons.

de Wilde, P. (2007). Politicisation of European integration: Bringing the process into focus (ARENA Working Paper No. 2007/18). Oslo: University of
Oslo. Retrieved from http://dx.doi.org/10.2139/ssrn. 2004986

Dür, A., \& Lechner, L. (2015). Business interests and the Transatlantic Trade and Investment Partnership. In M. Telò, F. Ponjaert, \& J. Morin (Eds.), The politics of transatlantic trade negotiations: TTIP in a globalized world (pp. 69-79). Farnham: Ashgate.

Edelman. (2020). 2020 trust barometer UK results. Edelman. Retrieved from https://www.edelman.co.uk/ research/2020-trust-barometer-uk-results

Eliasson, L. J., \& García-Duran Huet, P. (2018). TTIP negotiations: Interest groups, anti-TTIP civil society campaigns and public opinion. Journal of Transatlantic Studies, 16(2), 101-116.

European Commission. (2015). Online public consultation on investment protection and investor-to-state dispute settlement (ISDS) in the Transatlantic Trade and Investment Partnership Agreement. Brussels: European Commission. Retrieved from https://trade. ec.europa.eu/doclib/docs/2015/january/tradoc_ 153044.pdf

European Comission. (2016). Standard Eurobarometer 86. Brussels: European Comission. Retrieved from https://ec.europa.eu/commfrontoffice/public opinion/index.cfm/ResultDoc/download/ DocumentKy/79402

European Parliamentary Research Service Blog. (2015). Support for TTIP in EU Member States. European Parliamentary Research Service Blog. Retrieved from https://epthinktank.eu/2015/06/16/eu-usnegotiations-on-ttip-a-survey-of-current-issues/ support_for_ttip_in_eu_ms

Grande, E., \& Hutter, S. (2016). Beyond authority transfer: Explaining the politicisation of Europe. West European Politics, 39(1), 23-43.

Green, S., Gregory, C., Reeves, M., Cowan, J. K., Demetriou, O., Koch, I., \& Açiksöz, S. C. (2016). Brexit referendum: First reactions from anthropology. Social Anthropology, 24(4), 478-502.

Hutter, S., \& Grande, E. (2014). Politicizing Europe in the national electoral arena: A comparative analysis of five West European countries, 1970-2010. Journal of Common Market Studies, 52(5), 1002-1018.

Illot, O., Skelt, I., \& Rutter, J. (2017). Taking back control of trade policy. London: The Institute for Government. Retrieved from https://www.institute forgovernment.org.uk/publications/taking-backcontrol-trade-policy

Koch, I. (2017). Brexit beyond culture wars. American Ethnologist, 44(2), 225-230.

Lower courts can roll back EU laws after Brexit, No 10 confirms. (2019, December 18). The Guardian. Retrieved from https://www.theguardian.com/ politics/2019/dec/18/lower-courts-can-roll-backeu-laws-after-brexit-no10-johnson-confirms

Meet the man who negotiated trade for both the UK and the EU. (2019, April 19). Deutsche Welle. Retrieved from https://www.dw.com/en/meet-the-man-who- 
negotiated-trade-for-both-the-uk-and-the-eu/a48269945

Moore, M., \& Ramsay, G. (2017). UK media coverage of the 2016 EU referendum campaign. London: King's College London.

More people voted against Brexit parties than supported them. (2019, December 13). The New European. Retreived from https://www.theneweuropean.co.uk/ top-stories/more-than-52-of-the-general-electionvote-went-to-pro-remain-parties-1-6424196

Peters, B., \& Schaffer, J. (2013). The turn to authority beyond states. Transnational Legal Theory, 4(3), 315-335. https://doi.org/10.5235/20414005.4. 3.315

Startin, N. (2015). Have we reached a tipping point? The mainstreaming of Euroscepticism in the UK. International Political Science Review, 36(3), 311-323.

StopISDS. (n.d.). Action: Rights for people, rules for corporations. StopISDS. https://stopisds.org/action

Strange, M. (2013). A European identity in global campaigning? Activist groups and the 'Seattle to Brussels' network. Geopolitics, 18(3), 612-632

Trade Justice Movement. (2018). A trade model that works for everyone. Trade Justice Movement. Retrieved from https://www.tjm.org.uk/resources/ briefings/a-trade-governance-model-that-worksfor-everyone

UK Government. (2015). 2010 to 2015 government policy: Free trade. London: UK Government. Retrieved from https://www.gov.uk/government/ publications/2010-to-2015-government-policyfree-trade/2010-to-2015-government-policy-freetrade
UK Government. (2017). Trade white paper: Our future trade policy. London: UK Government. Retrieved from https://www.gov.uk/government/ publications/preparing-for-our-future-uk-tradepolicy

Vasilopoulou, S., Keith, D., \& Taalving, L. (2020). Emerging divisions on trade after Brexit (DEMOS Discussion Paper). London: Demos. Retrieved from https://demos.co.uk/wp-content/uploads/2019/10/ Emerging-divisions-on-trade.pdf

Vote Leave. (2016). Why vote leave. Vote Leave. Retrieved from http://www.voteleavetakecontrol.org/ why_vote_leave.html

War on Want. (2016). Response on Brexit from War on Want. War on Want. Retrieved from https:// www.justice-and-peace.org.uk/ttip/response-tobrexit-from-war-on-want

Young, A. R. (2017). The new politics of trade: Lessons from TTIP. Newcastle-upon-Tyne: Agenda Publishing.

Zappettini, F. (2019a). The Brexit referendum: How trade and immigration in the discourses of the official campaigns have legitimised a toxic (inter)national logic. Critical Discourse Studies, 16(4), 403-419

Zappettini, F. (2019b). The official vision for 'global Britain' Brexit as rupture and continuity between free trade, liberal internationalism and 'values.' In V. Koller, S. Kopf, \& M. Milgbauer (Eds.), Discourses of Brexit (pp. 140-154). Abindon: Routledge.

Zürn, M. (2004). Global governance and legitimacy problems. Government and Opposition, 39(2), 260-287.

Zürn, M. (2016). Opening up Europe: next steps in politicisation research. West European Politics, 39(1), 164-182.

\section{About the Author}

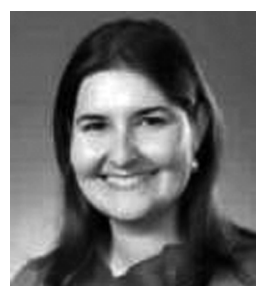

María García is a Senior Lecturer in the Department of Politics, Languages, and International Studies, University of Bath, UK. Her research focuses on the politics of trade agreements, geostrategic competition in free trade agreement networks, and the regulatory and societal impact of trade agreements. She runs a GW4 project on Brexit preparations in the South West and Wales, and is the co-editor of the Handbook of EU Trade Policy (Edward Elgar, 2018). 